\title{
WSG TEHNOLOGIJA U SLUŽBI HIDROTEHNIČKIH KONSTRUKCIJA
}

Major Janoš ${ }^{1}$

УДК: 626/627

DOI:10.14415/konferencijaGFS 2015.010

Rezime: U radu se nabrajaju opasnosti koji vrebaju na hidrotehničke konstrukcije i tim povodom prikazuju se neke materijalne i konstruktivne oštećenja na konstrukcijama.

WSG technologija se prikazuje sa osnovnim materijalom (aditivom) koji je razvijen $u$ Mađarskoj i proizvodnja je ponovo počela. Fizička i technička svojtva WSG aditiva se prikazuju u radu sa mogućim primenama u građevinarstvu. WSG aditiv u malterima $i$ betonima povećava trajnost hidrotehničkih konstrukcija - kod rezervoara za vodu, vodotornjeva, vodovodnih konstrukcija, bazena za plivanje - i svih konstrukcija koje su u podzemnoj vodi ili su ugroženi poplavama. Korištenjem WSG aditiva postiže se potpuna vodonepropusnost maltera i betona i otpornost protiv agresivnih materijala.

WSG aditiv se može koristiti u slučaju zagađenja okoline uljnim derivatima, može se primeniti za apsorpciju ulja sa vodenih površina i sa betonske površine.

Ključne reči : WSG tehnologija, vodonepropusnost, trajnost hidrotehničkih konstrukcija, zagadjenje uljnim derivatima.

\section{OŠTEĆENJA HIDROTEHNIČKIH KONSTRUKCIJA}

Kod hidrotehničkih konstrukcija [1] zbog prisustva vode ili vodene pare često dolazi do brze korozije materijala (Slika 1). Podzemne konstrukcije su stalno izložene uticaju podzemnih voda. Podzemni rezervoar $\left(500 \mathrm{~m}^{3}\right.$, Slika 2.) za termalnu vodu $\left(74{ }^{\circ} \mathrm{C}\right)$ je najostećenija $u$ zoni gde se stalno menja nivo vode. Korozija betonske armature je $\mathrm{u}$ tolikoj meri napredovala, da na nekim mestima u betonu su se stvarali krateri do dubine od $10-15 \mathrm{~cm}$.

\section{WSG ADITIV I TEHNOLOGIJA}

WSG aditiv [3] ima takva intenzivna hidrofobna svojtsva da sa umešanjem u cementni malter ili beton gotovi produkt pokazuje iste hidrofobne osobine, postaje „volumenski hidrofoban“ [2]. WSG aditiv ima fizičke osobine:

- 90 \% Ca O , zavisi od čistoće krečnjaka od kojeg se proizvodi,

- zapreminska gustoća je 400-450 kg/m³,

\footnotetext{
${ }^{1}$ Prof.dr habil. Major Janoš, dipl.inž.građ., Debreceni Egyetem Műszaki Kar, Debrecen, Hungary, drmajorjanos@gmail.com
} 


\section{$41^{\text {th }}$ ANNIVERSARY FACULTY OF CIVIL ENGINEERING SUBOtICA}

International conference

Contemporary achievements in civil engineering 24. April 2015. Subotica, SERBIA

- veličina zrna aditiva je 4-5 $\mu \mathrm{m}$,

- kontaktni ugao (contact angle) je $140^{\circ}$.

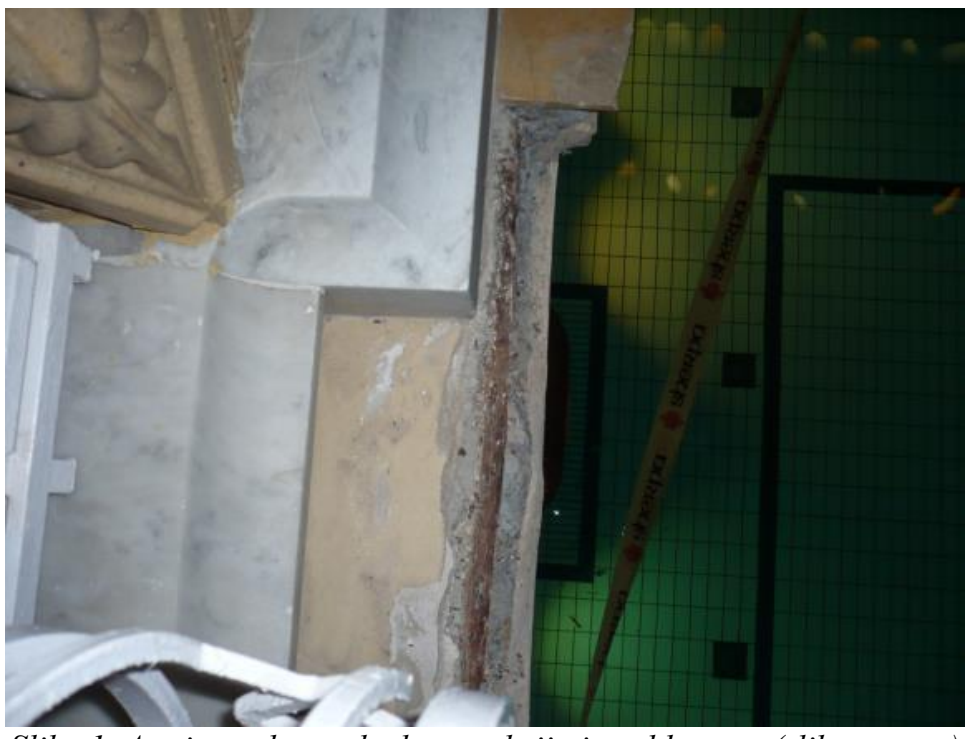

Slika 1. Armirano betonska konstrukcija iznad bazena (slika autora)

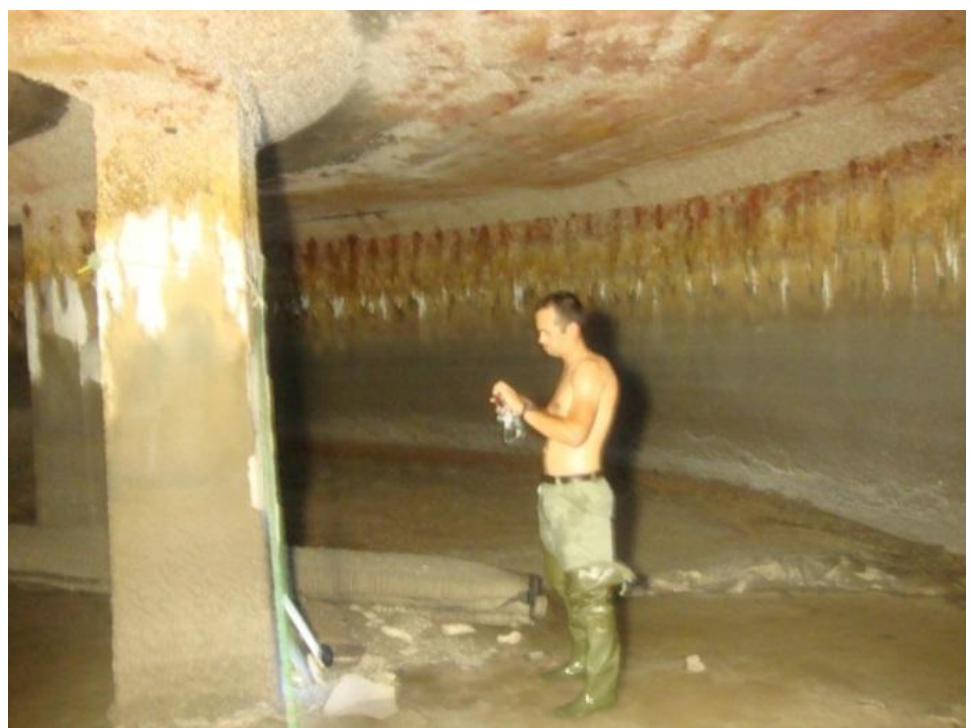

Slika 2. Podzemni rezervoar za termalnu vodu (slika autora) 


\section{1}
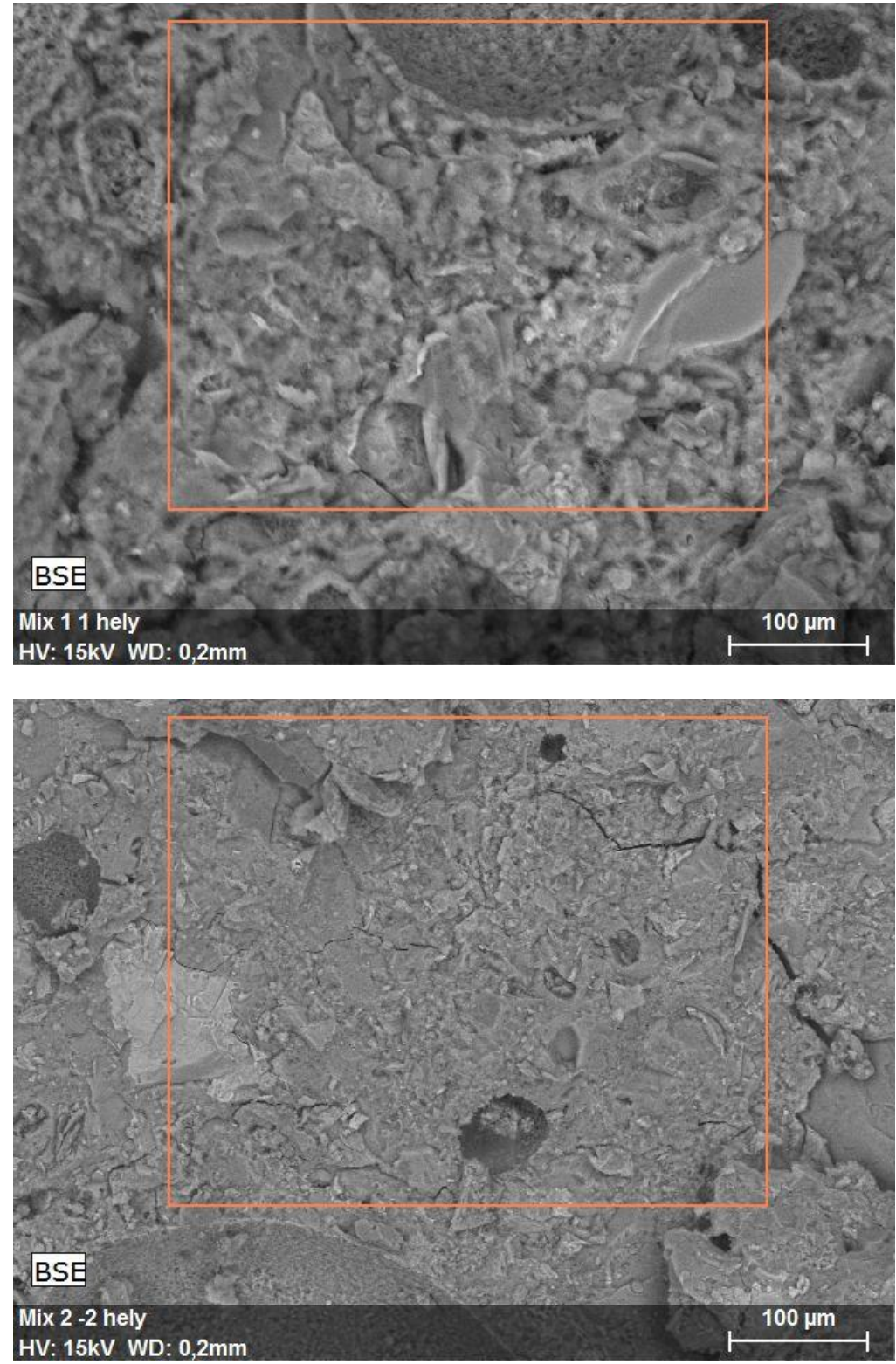

Slika 3. Snimak sa rentgenskim mikroskopom Mix 1 i Mix 2

Sprovedene su mikroskopske analize da bi utvrdili mehanizam delovanja WSG aditiva (Slika 3.). Prema nalazima utvrđeno je da WSG povećava procenat pora a malteru ili u betonu i time smanjuje pritisnu čvrstoću. Sa dobrim izborom cementa taj pad čvrstoće može se kompenzovati. 


\section{$41^{\text {th }}$ ANNIVERSARY FACULTY OF CIVIL ENGINEERING SUBOTICA}

International conference

Contemporary achievements in civil engineering 24. April 2015. Subotica, SERBIA

Mineralne analize (Slika 4.) potvrđuju da je WSG prirodni materijal i ne zagađuje okolinu.

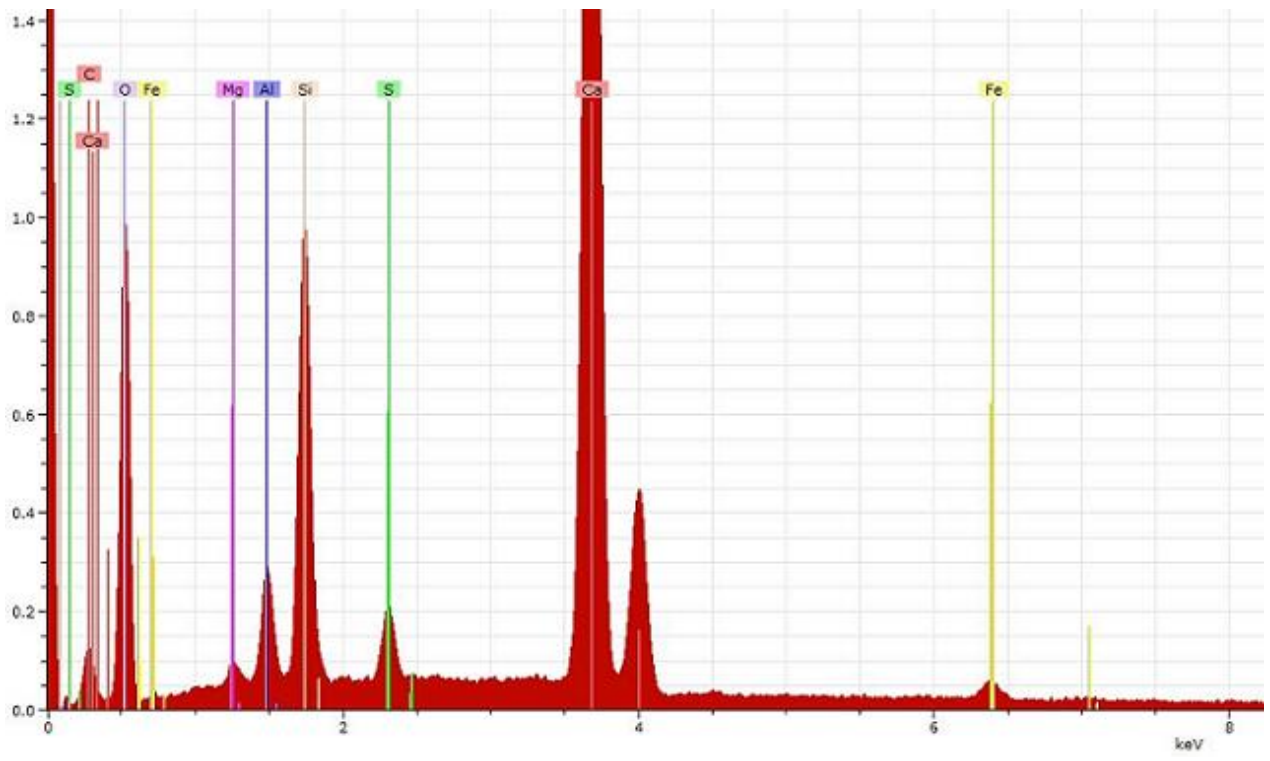

Slika 4. Rentgenski difraktogram betona

Primenom WSG aditiva malter i beton postaje otporan na uticaj soli $(10 \% \mathrm{Na} \mathrm{Cl})$ (Slika 5.). Na Slici 6. prikazana je tajna WSG tehnologije, u slučaju primene WSG maltera sa obe strane zida voda će biti potiskovana na dole i kapilarne sile nemaju moć za vertikalni transport vode, a u međuvremenu vrši intezivno sušenje zida.

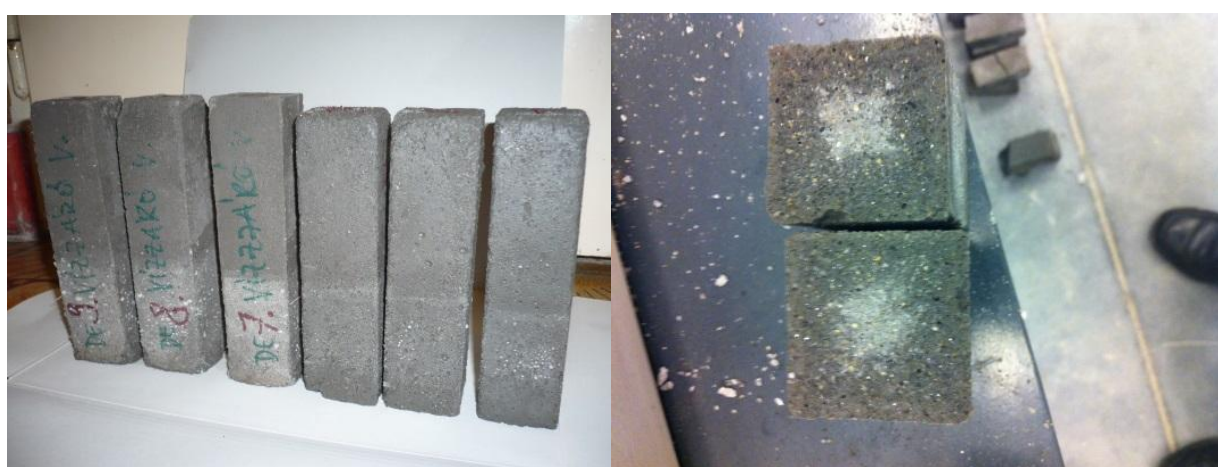

Slika 5. Rezultat lagerovanja uzoraka u rastvoru od $10 \% \mathrm{NaCl}$-a 


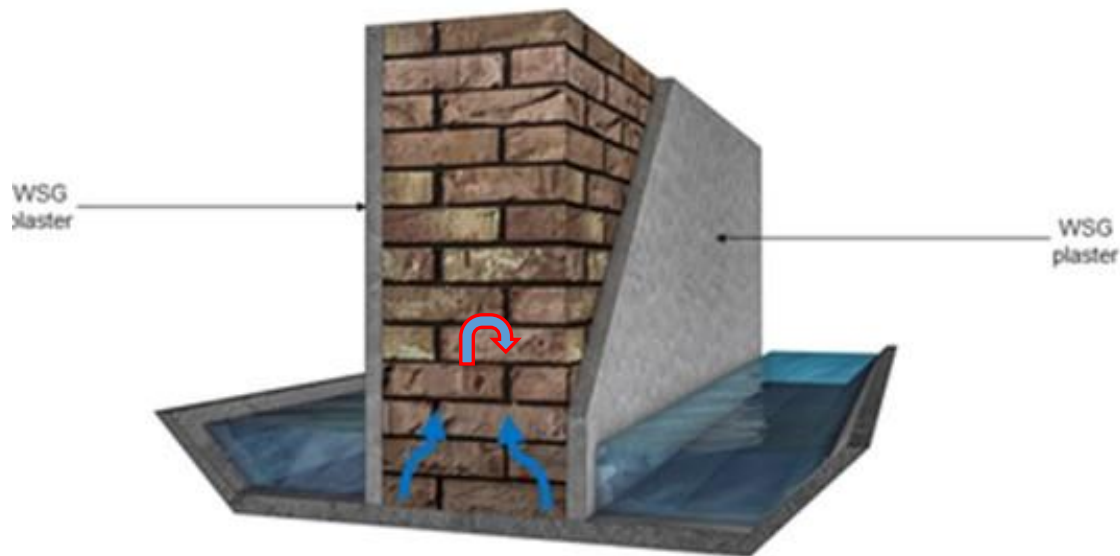

Slika 6. Funkcionisanje WSG tehnologije u slučaju primene na zidu

\section{WSG ADITIV U SLUŽBI ZAŠTITE OKOLINE}

U službi zaštite okoline možemo iskoristiti oilfil svojstva WSG aditiva da bi sakupili uljne derivate sa raznih površina. Za sakupljanje ulja potrebno je 400-500 g po litru ulja (Slika 7). Dobijena mešavina se može spaliti [3].
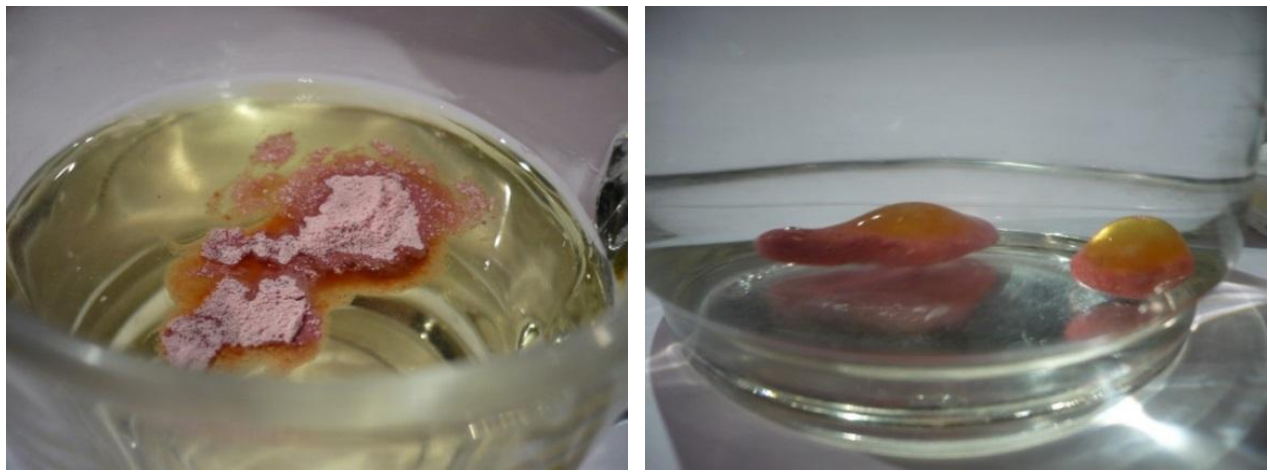

Slika 7. WSG upija uljne flekove na vodi

WSG aditiv možemo koristiti kod hidrotehničkih konstrukcija za povećavanje vodonepropusnosti:

- kod nasipa protiv visokih voda-poplava,

- kod intervencije za vreme odbrane od poplave,

- kod svih betonskih konstrukcija gde je vodonepropusnost zahtev,

- kod hidroizolacija korita zemljanih jezera,

- za intervencione svrhe u slučaju havarija na sistemu vodosnabdevanja, 


\section{$41^{\text {th }}$}

International conference

Contemporary achievements in civil engineering 24. April 2015. Subotica, SERBIA

- za intervencione svrhe u slučaju havarija na kanalizacionom sistemu.

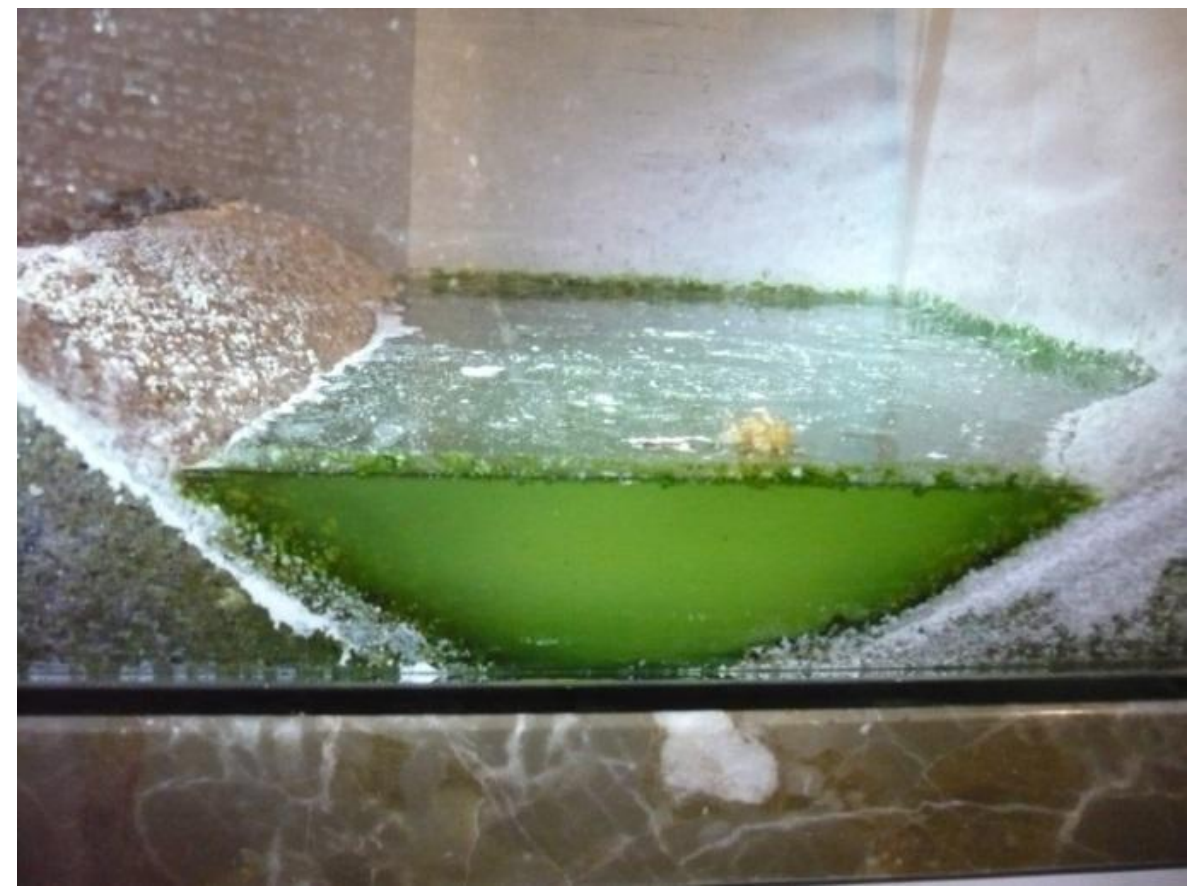

Slika 8. WSG aditiv osigurava za vreme poplave vodonepropusnost nasipa

\section{LITERATURA}

[1] János Major: Magyar Hidrológiai Társaság 31. Vándorgyülése, Gödöllő, 2013 http://www.hidrologia.hu/vandorgyules/31/dolgozatok/word/096 major janos.pdf

[2] János Major: The water repellent treatment of building materials in thermal baths, Hydrophobe VII., International Conference, Lisbon, 2014

[3] WSG Kft.: http://www.worldstrongguard.hu, 2015 
Међународна конференција

Савремена достигнућа у грађевинарству 24. април 2015. Суботица, СРБИЈА

\title{
THE WSG TECHNOLOGY IN THE SERVICE OF WATER UTILITIES
}

\begin{abstract}
Summary: The paper summarized the damage mechanisms of water utilities and goes on presenting the WSG products and their area of use with physical and technical characteristics. The high value added, innovative, independent, domestic (hungarian) designed products that are basically cement based, are exposed to the effects of environment and the WSG technology provides the durability of outdoors and indoors structures and ensures their usage lifetime. By making use of the WSG products it can increase the durability of water utility structures-drinking water, water reservoirs, thermal water, swimming pools, tanks, pipelines-furtherly all building structures that were damaged by ground-water, precipitation of floods. By using the products it could manufacture insulating, watertight mortar or concrete that resist the aggressive materials. WSG products are effectively used as saving material in case of natural catastrophies, for example it could decrease the damage caused by petroleum and its derivatives with an environmental friendly technology: with the help of the products the polluting substances can be collected/removed from water surfaces or solid material surfaces, and thus the environment is handled protectively.
\end{abstract}

Keywords: WSG technology, durability of water utility structures, petroleum polluting. 